\title{
PEMBELAJARAN MUSIK MENGGUNAKAN GELAS BERBAHAN KACA PADA MAHASISWA JURUSAN PAUD FIP UNY \\ TAHUN AJARAN 2016/2017
}

\author{
Rina Wulandari \\ Jurusan PAUD FIP UNY \\ rina_wulandari@uny.ac.id
}

\begin{abstract}
Abstrak
Tujuan penelitian ini adalah untuk mendeskripsikan pembelajaran musik menggunakan gelas berbahan kaca pada mahasiswa jurusan PAUD FIP UNY tahun angkatan 2016/2017. Metode penelitian menggunakan jenis deskriptif. Sumber data penelitian adalah komponen pembelajaran dalam permainan musik gelas berbahan kaca. Teknik pengumpulan data menggunakan observasi, dokumentasi, dan wawancara. Analisis data menggunakan model interaktif, yaitu pengumpulan data, reduksi data, display data, kesimpulan/verifikasi. Uji kredibilitas menggunakan perpanjangan pengamatan. Hasil penelitian yaitu pembelajaran dilaksanakan dengan urutan: 1). pengenalan unsur irama menggunakan software Sibelius seri 6, metode Takadimi, jenis birama, pengulangan harafiah dari ilmu bentuk lagu; 2) melodi; 3) harmoni; 4) kaden; 5) bentuk lagu dua bagian; 6) progresi harmoni/ akor; 7) tempo jenis sedang; 8) penggunaan Wine Glass; 9). Teknik memainkan gelas adalah dengan cara menyentuhkan jari-jari tangan terhadap bibir gelas/ teknik menyentuhkan satu sama lain; 10). Kondisi jari tangan haruslah terbebas dari segala macam bentuk minyak; 11). Gelas direkatkan di meja; 12). Perolehan nada berurutan dari total setengah lusin gelas adalah sejumlah 5 gelas; 13) jumlah air berpengaruh pada nada yang dihasilkan; 14) menggunakan alat pengukur tinggi rendah nada yaitu aplikasi sejenis tuner dan aplikasi piano.
\end{abstract}

Kata Kunci: musik, gelas, kaca

\section{MUSIC LEARNING USING GLASSES TO THE STUDENTS IN EARLY CHILHOOD EDUCATION DEPARTEMENT, FACULTY OF PEDAGOGY, YOGYAKARTA STATE UNIVERSITY IN THE 2016/2017 ACADEMIC YEAR}

\begin{abstract}
The purpose of this study is to describe the learning of music using glass made from glasses in the students majoring in PAUD FIP UNY year force 2016/2017. The research method used descriptive type. Sources of research data is a component of learning in glass music game made from glass. Data collection techniques used observation, documentation, and interviews. Data analysis using interactive model, that is data collection, data reduction, data display, conclusion /verification. The credibility test uses an extension of observation. The result of this research is that learning is carried out in order of: 1). The introduction of rhythmic elements using Sibelius software series 6, Takadimi method, bar type, literal repetition of the science of song form; 2) melody; 3) harmony; 4) kaden; 5) two- piece song form; 6) progression of harmony / chord; 7) medium tempo; 8) the use of Wine Glass; 9). The technique of playing glass is by touching the fingers of the glasses / techniques touching each other; 10). The condition of the fingers must be free from all forms of oil; 11). The glass was glued to the table;12). The consecutive tone recording of a total of half a dozen glasses is 5 cups; 13) the amount of water effect on the resulting tone; 14) using a low-tone gauge that is a similar application tuner and piano applications.
\end{abstract}

Keyword: music, glasses 


\section{PENDAHULUAN}

Gambaran umum dari observasi/ pengamatan dan fenomena dalam tulisan ini adalah bahwa permainan musik menggunakan alat musik yang pada umumnya digunakan, seperti gitar, piano, drum, bass gitar, dan semacamnya, dirasa merupakan hal yang telah biasa terjadi dan ada di masyarakat pada umumnya. Fenomena video dengan alamat https://www.youtube.com/watch?v=hWsn hywwPgI memberikan hal inovatif dan kreatif terkait performance dalam bidang musik.

Video tersebut sekaligus memberikan ide kepada penulis untuk melakukan survey kualitas gelas penghasil nada yang telah dilakukan sebelum tulisan ini dirilis. Dalam survey tersebut telah ditemukan bahwa gelas kaca dengan sebutan Wine Glass, secara fisik, memang gelas yang paling mudah untuk digunakan dalam permainan musik.

Berdasarkan hasil survey tersebut, penulis juga mendapatkan ide untuk mengetahui kualitas nada yang dihasilkan dari gelas berbahan kaca tersebut dalam keadaan kosong. Kosong dalam konteks ini adalah tanpa adanya tambahan air dalam gelas. Dalam video tersebut, penulis juga mengamati adanya berbagai macam ukuran Wine Glass beserta air yang mengisinya serta teknik memainkan menggunakan jari-jari tangan dimana hal ini juga telah penulis tulis dalam karyakarya tulis sebelumnya.

Penulis mengamati bahwa semakin besar ukuran gelas maka nada juga semakin rendah. Begitupun sebaliknya, semakin kecil ukuran gelas, maka, juga menghasilkan nada yang tinggi. Cairan yang digunakan dalam video tersebut adalah air. Cara memainkan gelas adalah gesekan antara jari tangan dan bibir gelas.

Berdasarkan video tersebut maka penulis menerapkannya dalam pembelajaran musik dalam mata kuliah Estetika Instrumental untuk Anak Usia Dini yang dilaksanakan tiap semester ganjil. Melalui jenis penelitian deskriptif ini, maka, dihasilkan deskripsi pembelajaran musik menggunakan gelas berbahan kaca yang dilakukan pada mata kuliah Estetika Instrumental Anak Usia Dini mahasiswa PAUD FIP UNY.

\section{METODE PENELITIAN}

1. Waktu pelaksanaan penelitian, dilakukan pada semester ganjil pada mata kuliah estetik instrumental untuk anak usia dini tahun ajaran 2016/2017 yang berlangsung antara bulan september 2016 sampai januari 2017.

2. Tempat penelitian berlangsung di kampus UPP 2 jalan Bantul nomor 50.

3. Bahan dan alat yang digunakan adalah gelas jenis Wine Glass berbagai ukuran, lakban, meja, sabun pencuci tangan anti minyak, software Sibelius seri 6, air mineral, aplikasi jenis tuner, dan aplikasi jenis piano.

4. Metode pemerolehan data menggunakan observasi.

5. Teknik analisis data menggunakan model interaktif, yaitu pengumpulan data, reduksi, verifikasi.

\section{HASIL DAN PEMBAHASAN}

Sumber data penelitian ini adalah komponen pembelajaran dan musik. Batasan istilah untuk komponen pembelajaran adalah materi pembelajaran. Batasan istilah untuk musik adalah irama (nilai not, tempo, tanda birama, ruas birama), melodi (tangganada natural), harmoni (progresi akor), lagu dua bagian, kaden (sempurna/ perfect cadens dan setengah/ half cadens), dan sekuen (naik dan turun).

Hasil penelitian pada materi pembelajaran yaitu: 1). Pembelajaran diawali dengan pengenalan unsur irama menggunakan software Sibelius seri 6 . Dosen membuka software Sibelius6 sebagaimana terdapat dalam gambar berikut ini: 


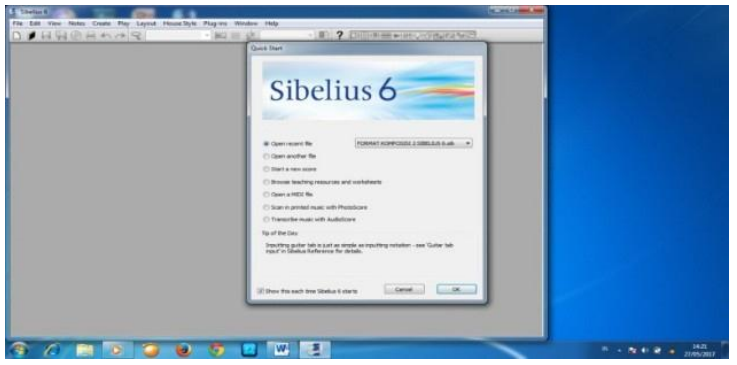

Software ini digunakan karena disesuaikan dengan sistem windows yang ada di laboratorium komputer Kampus 3 Jalan Bantul No.50.

Langkah pertama adalah memilih Star a new score, lalu pilih pop group (salahsatu gaya musik yang pada umumnya digunakan di khalayak), lalu atur penggunaan instrumen musik dengan memilih change instrument seperti dalam gambar berikut ini:

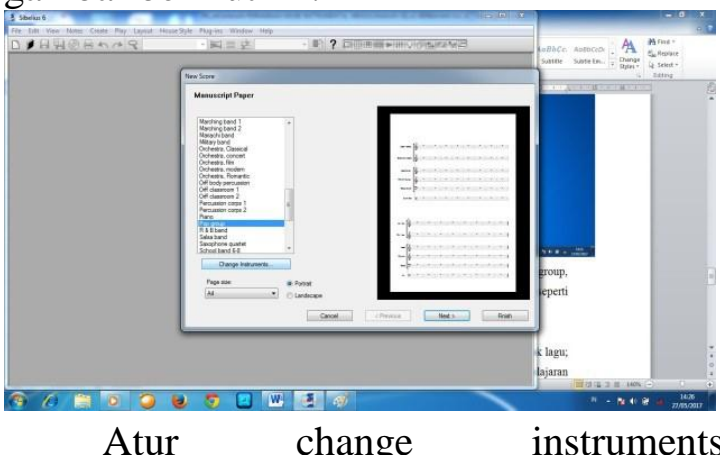

menggunakan delete from score ataupun add to score, seperti dalam gambar berikut:

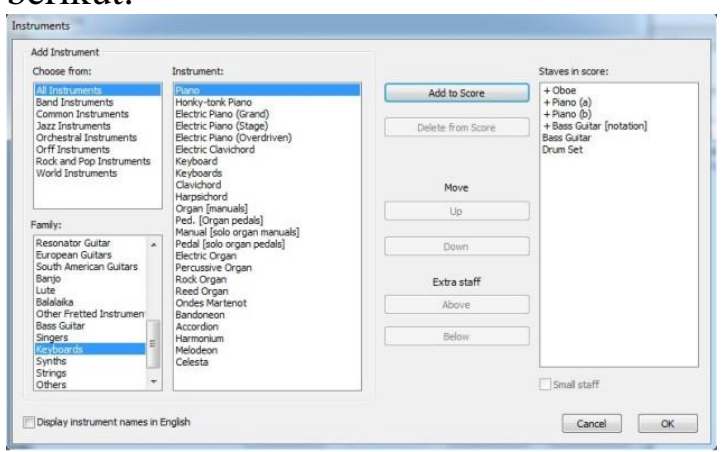

Pilihan alat musik tersebut berdasarkan pada alat musik yang biasanya terdapat di khalayak umum pada jenis musik pop. Oboe digunakan dalam calon naskah musik tersebut karena bunyi panjang dan pendek lebih konsisten terdengar bila dibandingkan dengan string. Susunan alat musikpun diatur sedemikian rupa sehingga urutannya menjadi seperti ini: paling bawah adalah drum set, kemudian di atasnya adalah bass guitar, disusul piano, kemudian terakhir adalah Oboe. Jika klik OK untuk membuat draft karya. Atur port trait dan atau landscape yang akan digunakan terkait page size kertas. Untuk antisipasi kekurangan ruang saat menuliskan syair lagu, sebaiknya menggunakan page size jenis landscape.

Bagian layar yang bertulis House Style tidak ada perubahan, klik Next, sesuaikan Time signature and Tempo. Time Signature dapat disesuaikan dengan gaya musik yang akan digunakan. Jenis 3/4 sering dikenal dengan gaya musik Waltz. Jenis 4/4 banyak terdapat dalam gaya musik populer saat ini. Centang Metronome mark dan ganti angka yang semula 100 menjadi tempo dengan kecepatan 80. Hal ini karena cepat-lambat lagu yang baik untuk anak adalah tidak terlalu cepat dan tdak terlalu lambat sehingga tempo jenis 80 merupakan tempo jenis sedang, kemudian klik Next.

Bagian berikutnya adalah Key Signature, biarkan dalam keadaan tangganada Natural atau do=c. Hal ini dikarenakan jangkauan tangganada natural merupakan jangkauan wilayah nada yang sesuai dengan jangkauan suara yang sedang dialami oleh anak-anak. Bukankah pita suara anak sedang dalam keadaan tumbuh dan berkembang? Bukankah pita suara tersebut belum sesempurna pita suara milik orang dewasa? Jawabannya tentulah IYA. Berikut gambarnya:

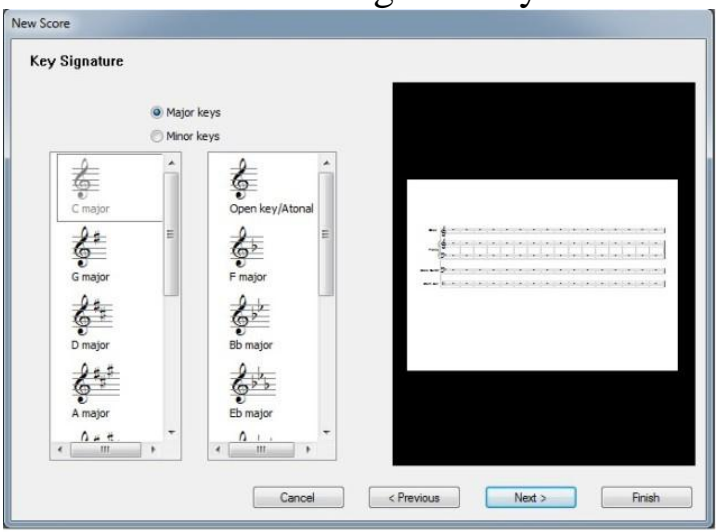

Lengkapi dengan informasi karya komposisi musik yang akan diciptakan seperti dalam gambar berikut ini: 


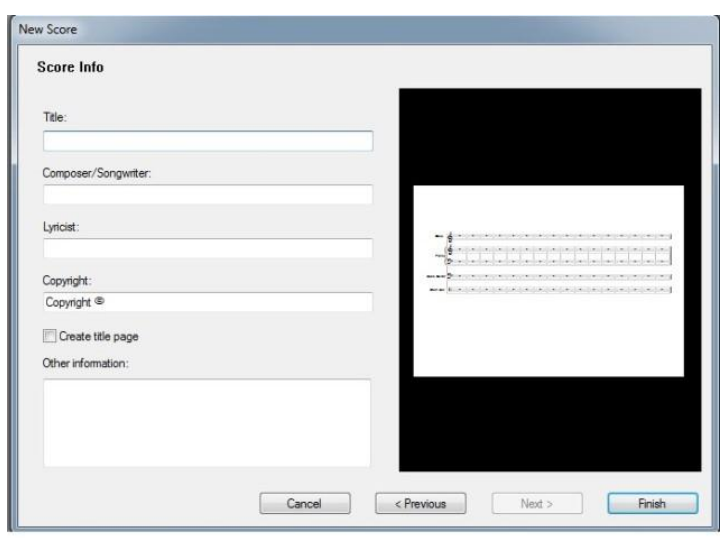

Dilanjutkan dengan mengatur jumlah ruas birama tiap baris. Klik garis birama tunggal pada ruas birama ke 4 lalu klik enter. Lanjutkan pada ruas birama 8, 12, dan 16. Seperti gambar berikut ini:

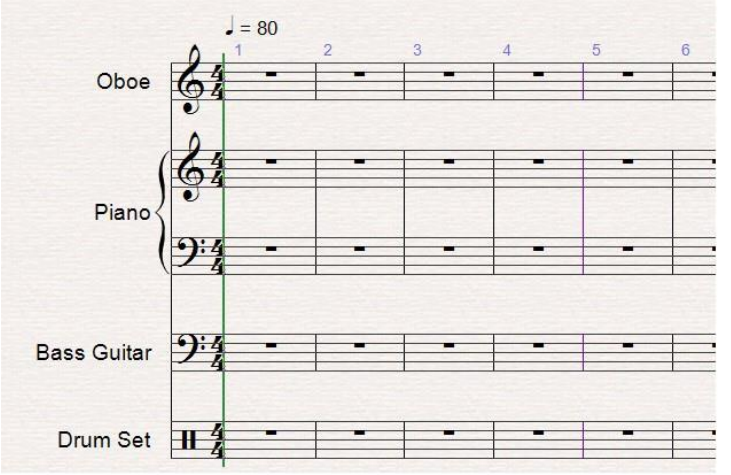

Tambahkan 4 ruas birama yang akan digunakan sebagai intro lagu. Intro lagu diambil dari 4 ruas birama terkahir. Jumlah total ruas birama adalah 20. Dalam zoom level $25 \%$ terlihat sebagai berikut:

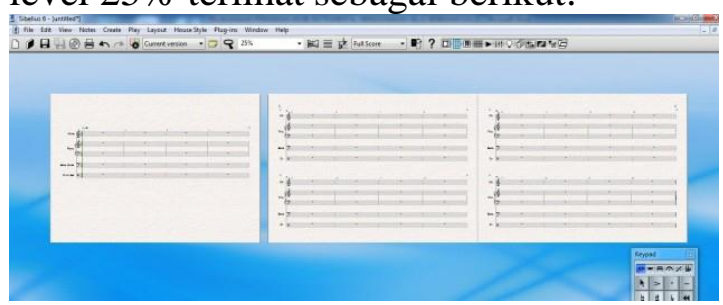

Materi berikutnya adalah metode Takadimi, jenis birama, dan pengulangan harafiah dari ilmu bentuk lagu. Nilai Quarter Note dan Eight Note merupakan nilai yang mudah dimainkan oleh anak jika digunakan dalam komposisi musik yang menggunakan jenis birama 2, 3, maupun 4 dengan tempo 80 .

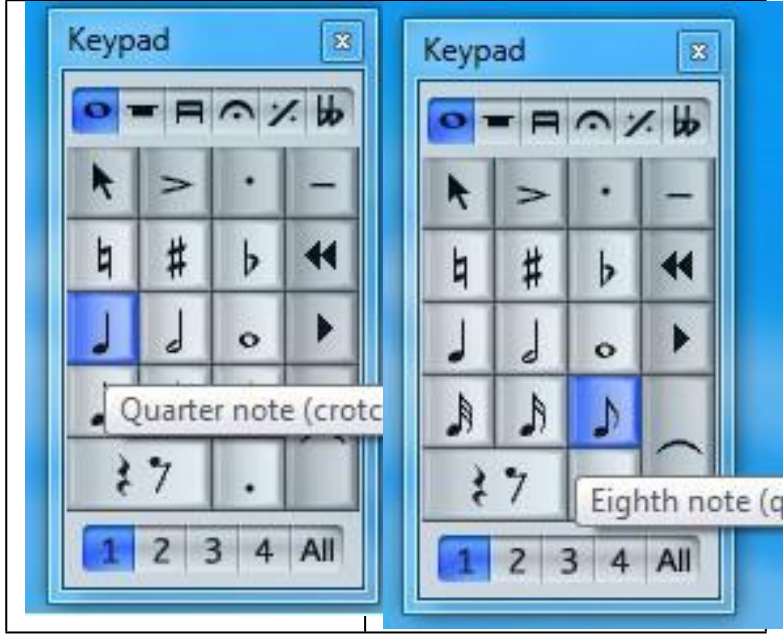

Berdasarkan observasi dan wawancara saat praktek memainkan ritme, didapatkan data bahwa jenis birama 2/4 dan 4/4 merupakan jenis birama yang mudah dimainkan oleh mahasiswa sebagai calon guru bila dibandingkan dengan jenis birama 3/4. Dalam tugas akhir kuliah maka mahasiswa disilahkan menggunakan jenis birama 4/4. Pengulangan harafiah adalah mengulang ritme secara langsung. Berikut gambarnya:

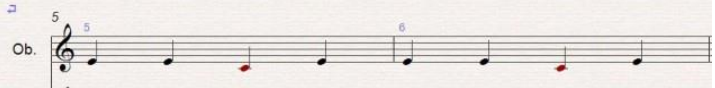

Karl Edmund Prier SJ (1996: 26-34) menyatakan bahwa dalam sebuah lagu, terdapat ilmu analisis motif. Motif mempunyai ciri khas diantaranya adalah setidak-tidaknya terdiri dari 2 nada dan maksimal memenuhi 2 ruas birama. Jika hanya memenuhi satu ruas birama maka disebut motif birama. Jenis pengolahan motif diantaranya adalah harafiah, sekuen, pembesaran interval, pengecilan interval, pembalikan, dan pembesaran nilai nada. Dalam perkuliahan tersebut pengolahan motif yang digunakan adalah harafiah dan sekuen. Dalam bukunya, Karl menjelaskan bahwa harafiah lebih menegaskan pesan sedangkan sekuen adalah variasi termudah.

Materi dilanjutkan dengan unsur melodi. Melodi membahas tentang pitch atau tinggi-rendah nada. Tangganada $\mathrm{c}$ mayor merupakan wilayah suara yang aman untuk anak. Berikut gambarnya:

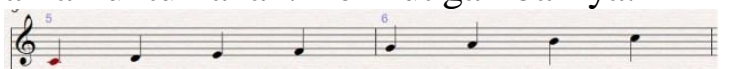


Dari gambar di atas, maka seringkali lagu-lagu anak di lapangan sulit ditirukan oleh anak dengan tepat nadanya, hal ini kemungkinan terdapat kekurangsesuaian pada pemilihan jangkauan wilayah nada. Penulis pernah mengamati pelaksanaan lomba menyanyi. Kemampuan vokal dan rasa percaya diri si anak yang akan ikut lomba sangat bagus. Namun sangat disayangkan bahwa musik yang digunakan untuk mengiringi si anak saat lomba tidak sesuai jangkauan wilayah nadanya. Tangganada yang digunakan dalam iringan si anak tersebut terlalu rendah. Bukankah ini dapat diperbaiki?

Materi dilanjutkan pembelajaran unsur harmoni/ trinada. Unsur harmoni merupakan unsur yang erat kaitanyya dengan akor. Dari tangganada c mayor tersebut, dapat disusun tujuh buah akor. Berikut gambarnya:

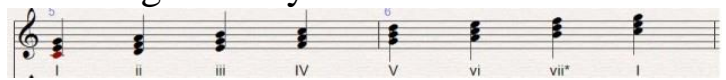

Dari jenis akor tersebut maka terdapat progresi akor, modelnyapun bermacammacam. Bruce Benward and Marilyn Saker (2008: 215) menyebutkan bahwa salahsatu model progresi akor adalah I-I-V-I. Oleh karena itu, akor yang digunakan dalam komposisi musik dalam perkuliahan diantaranya adalah model tersebut. Masing-masing simbol akor menempati ruas birama $5,6,7$, dan 8 .

Berikutnya adalah materi kaden. Bruce Benward and Marilyn Saker (2008: 98-99) menjelaskan bahwa cadence atau kaden ibaratnya adalah seperti tanda titik dan tanda koma dalam menulis karya. Kadens terdapat 3 macam yaitu 1) perfect authentich cadence, "... the perfect authentic cadence is a progression from $V$ to $I$ in major keys and $V$ to $i$ in minor keys..”; 2) Plagal Cadence, “...The plagal cadence is nearly always one progression: IV to I in major keys, or its equivalent,iv to $i$ in minor keys..."; 3) Half Cadence, "...If the second chord of a cadence is $V$, it is a half cadence...". Dalam perkuliahan tersebut, kaden yang digunakan adalah perfect authentich cadence dan half cadence. Perfect authentich cadence ditempatkan pada akhir ruas birama, yaitu ruas birama ke-20 sedangkan half cadence ditempatkan di ruas birama ke-8.

Berikutnya adalah materi bentuk lagu, yaitu lagu dua bagian. Karl Edmund Prier SJ (1996: 7) menyatakan bahwa lagu dua bagian adalah jenis bentuk lagu yang pada umumnya digunakan pada musik sehari-hari. Termasuk di dalamnya yaitu lagu anak, daerah, pop, lagu instrumental untuk iringan tari, dan semacamnya. Lagu dua bagian dalam materi kuliah tersebut terdiri dari:

1. Ruas birama 1 sampai dengan 4 sebagai intro. Intro diambil dari ruas birama 17 sampai dengan 20 .

2. Ruas birama 5 sebagai motif kemudian diharafiahkan ke ruas birama 6. Harafiah adalah pengulangan secara langsung, tanpa ada selingan ruas birama. Ilmu harafiah bunyi lebih memudahkan dalam mengingat nada. Seperti dalam gambar berikut ini:

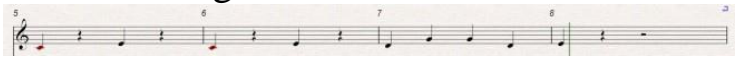

Gambar tersebut menunjukkan bahwa susunan nada pada ruas birama 5 dan 6 sama persis. Itulah harafiah. Jika dibunyikan, nadanya sangat mudah diingat karena hanya pengulangan dari bunyi yang sudah terdengar sebelumnya. Ruas birama 8 hanya berisi satu not quarter karena jika nantinya nada tersebut diisi syair, maka tanda rest yang mengikutinya berfungsi sebagai "saat bernafas" saat menyanyi. Begitupun pada ruas birama 12, 16, dan 20. Ruas birama 7 dapat berbeda dengan ruas birama 5 dan 6 .

3. Ruas birama 9 sampai 12 merupakan harafiah dari ruas birama 5 sampai 8 .

4. Ruas birama 12 merupakan ruas birama yang wajib menggunakan akor $\mathrm{V}$ karena ruas birama ini adalah ibarat tanda koma dalam karya tulis. Seperti dalam gambar berikut: 


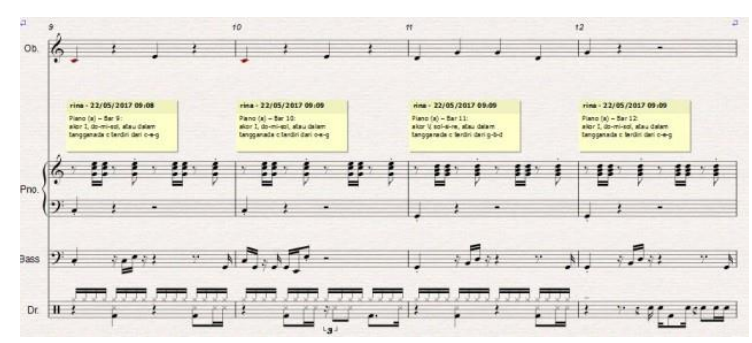

5. Ruas birama 13 dan 14 juga menggunakan harafiah, namun karena penggunaan akor yang berbeda, maka, harafiah sebatas pada ritme saja, sedangkan melodi disesuaikan dengan akor yang digunakan. Seperti dalam gambar berikut:

Ruas birama 13 menuju 14 merupakan penerapan ilmu sekuen atau pengulangan namun dalam tingginada yang berbeda. Jika diperhatikan, gerak nada ruas birama 13 dan 14 adalah sama.

6. Ruas birama ke 17 sampai dengan 20 merupakan harafiah dari ruas birama 13 sampai dengan 16 . Ruas birama ke 20 sedikit berbeda karena ruas birama ke 20 merupakan akhir lagu sehingga wajib menggunakan kaden sempurna dimana melodi harus jatuh ke nada do. Seperti dalam gambar berikut:

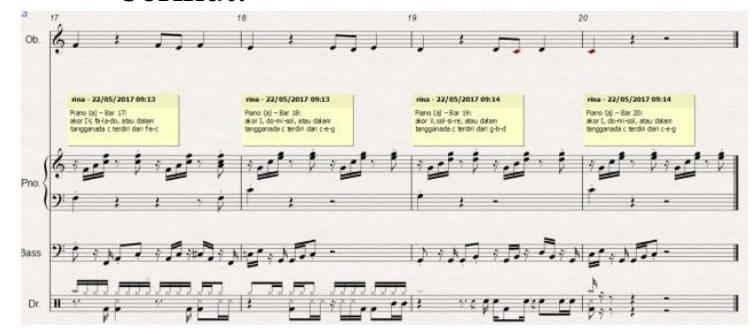

Rekomendasi penggunaan Wine Glass. Jenis gelas ini representatif digunakan dalam pembelajaran musik. kemudian teknik memainkan gelas adalah dengan cara menyentuhkan jari-jari tangan terhadap bibir gelas/ teknik menyentuhkan satu sama lain. Dapat dilakukan pada salahsatu bidang bibir gelas dengan cara stacatto ataupun dengan menyentuhkan jari tangan memutar seiarah jarum jam pada bibir gelas. Kondisi jari tangan haruslah terbebas dari segala macam bentuk minyak, termasuk sejenis pelembab tangan. Tangan hendaknya dicuci terlebih dahulu menggunakan cairan pencuci tangan. Gelas ditata sejajar di meja kemudian direkatkan menggunakan sejenis lakban. Perolehan nada dari total setengah lusin gelas adalah sejumlah 4 gelas dengan menghasilkan 4 nada berurutan.

Perolehan 4 nada dari tiap setengah lusin gelas adalah menggunakan air jernih. Jumlah air berpengaruh pada nada yang dihasilkan. Makin banyak jumlah air dalam gelas maka nada semakin rendah. Dalam perolehan nada, maka dosen menggunakan alat pengukur tinggi rendah nada yaitu aplikasi sejenis tuner dan aplikasi piano.

\section{PENUTUP}

Berdasarkan pertanyaan penelitian maka dapat disimpulkan bahwa: Pembelajaran diawali dengan pengenalan unsur irama menggunakan software Sibelius seri 6, metode Takadimi, jenis birama, pengulangan harafiah dari ilmu bentuk lagu; dilanjutkan dengan unsur melodi; unsur harmoni/ trinada; materi kaden; materi bentuk lagu, yaitu lagu dua bagian; materi tentang progresi harmoni/ akor. Rekomendasi penggunaan Wine Glass. Teknik memainkan gelas adalah dengan cara menyentuhkan jari-jari tangan terhadap bibir gelas/ teknik menyentuhkan satu sama lain.

Kondisi jari tangan haruslah terbebas dari segala macam bentuk minyak, termasuk sejenis pelembab tangan; gelas ditata sejajar di meja kemudian direkatkan menggunakan sejenis lakban. Perolehan nada dari total setengah lusin gelas adalah sejumlah 5 gelas dengan menghasilkan 5 nada berurutan. Jumlah air berpengaruh pada nada yang dihasilkan. Makin banyak jumlah air dalam gelas maka nada semakin rendah. Menggunakan alat pengukur tinggi rendah nada yaitu aplikasi sejenis tuner dan aplikasi piano. 
Jurnal Pendidikan Anak, Volume 6, Edisi 1, Juni 2017

\section{DAFTAR PUSTAKA}

Benward, B., Saker M. (2008). Music in Theory and Practice, Vol. 1 , Eighth Edition-McGraw-Hill.

Prier S.J.K.E. (1996). Ilmu Bentuk Musik. Pusat Musik Liturgi. Yogyakarta.

Finn, B., Finn, J. (2009). Sibelius 6. Frankfut. Germany. 